\title{
Interglobular Spaces in Some Mammalian Teeth
}

\author{
by \\ Sohiti ISOKAWA*, Tadasu NISHIHARA*, \\ Tsuguo OYANAGI*, Masao MORIMOTO*, Saburo YAMAGUCHI* \\ and Kaoru KUWAJIMA* Masahiko AJISAKA*
}

COHEN[1] ascribes a statement to ToMEs to the effect that the interglobular spaces are caused by an imperfect calcification of dentin. In 1850, CzERMAK[2] of Germany coined the term Interglobularräume and, later on, these interglobular spaces were assumed or interpreted by Kölliker[3], McQuillen[4] and Kollmann[5] to be that portion of hypocalcified area occured by an imperfect union of calcospherites appearing in the calcification of dentin through its formative process.

In the published native literature, IsoKAwA et al.[6] established the interglobular space as an imperfectly calcified portion as a result of their historadiographic analysis.

In an effort to study universal morphology of the interglobular space, KATAYAMA [7], Nishiyama[8], ERva[9] and Nakajima[10] used the permanent teeth, whereas IsOKAWA et al.[11] made use of the deciduous teeth, the latter carrying out observations by means of semi-serial ground sections. Consensus of their opinions indicates that the interglobular space can be regarded as a universal structure except for the deciduous incisors and canines in man.

On the other hand, FuJITA[12] in his textbook on Dental Histology describes that the interglobular space is altogether lacking in teeth other than those of man and, if there should be found at all, it is a very rare phenomenon. However, as early as in 1926 BREUER[13] attested to the existence of this interglobular space in the badger (Meles anakuma), AdolfF[14] in the seaunicon (Monodon), and Dieckmann[15], GoldBerG[16] and MuMmery[17] respectively found the interglobular space in a few species of mammalians. Inspite of these published findings, however, it is not possible to state definitely that the interglobular space is a universally found structure in the mammalian teeth: the reason is that the space is not invariably found in every tooth of the same mammalian dentition. Usual practice of preparing one or two ground sections from one tooth certainly leaves room for a possibility of missing the interglobular space even if it exists there.

In the present study, the authors concerned themselves with semi-serial ground sections prepared from as many as 21 mammalians in order to ascertain the existence of this space in them.

\section{Materials and Method}

By way of study materials, 69 teeth from 21 mammalians were used (Table 1).

\footnotetext{
* 磯川宗七, 西原是, 大柳次男, 森本昌男, 山口三郎, 桑島馨 鯥坂正彦, Department of Anatomy, Nihon Univ. School of Dentistry, Tokyo
} 


Primates
Anthropopithecus niger
Hylobates lar
Macacus cynomolga
Carnivora
Ursus thibetanus japonicus
Ursus arctos yesonesis
Phoca vitulina
Nyctereutes procyonoides viverrinus
Canis familiaris
Feris pardus
Feris domestica
Artiodactyla

Primates

Anthropopithecus niger

Hylobates la

us cynomolga

Ursus thibetanus japonicus

yesonesis

Phoca vitulina

Canis familiaris

Artiodactyla

Camelus dromedarius
Table 1

Sus scrofa

Sus leucomystax

Bos taurus

Capra hircus

Hydropotes inermis argyropus

Cetacea

Delphinus delphis

Berardius

Globicephala

Perissodactyla

Equus caballus

Marsupialia

Macropus rufus

A group of 4 teeth were ordinarily selected from one species: 2 anteriors either incisor or canine and 2 posteriors molar or premolar. In five species, however, of the leopard (Felis pardus), kangaroo (Macropus), chimpanzee (Anthropopithecus niger), bear (Ursus arctos yesoensis) and monkey (Hylobates lar) only one anterior or posterior. Except for the goat teeth which were deciduous, all the rest were permanent. As the whale (Cetacea) is classified as homodontia and monophyodont, there exists no distinction between the permanent and decidous teeth or between the anteriors and posteriors.

All of 69 specimens were dehydrated by alcohol and after they had been immersed in a solution of aceton for 7 days, they were embedded in polyester resin. By the use of Gilling-Bronwill thin sectioning machine, they were cut to produce semi-serial ground sections to the thickness of 80 to 150 microns. Such large molars as those of the horse (Equus caballus) and camel (Camelus dromedarius) were cut into 2 or 3 divisions prior to their embedding in plastic resin.

These semi-serial ground sections were made into permanent preparations without staining and were subjected to careful microscopic observations so as to ascertain the existence of interglobular space. Those in which the existence of interglobular space was obscurely attested were further polished to the thickness of 40 to 70 microns and their contact historadiographs were obtained by the ultra soft X-ray unit of Softex CMR type. Historadiographs were then studied microscopically.

\section{Observations}

Although it was far from an easy task to confirm the existence of interglobular space in the animals under study, painstaking microscopic observations could find interglobular spaces in almost all the teeth examined. Particularly, the historadiographic technique helped the confirmation of interglobular space, even if it was just a trace, interglobular space appears as radiolucent. Figures 1 to 4 show respective interglobular spaces observed in the dog, seal, wild pig and racoon dog.

It was impossible to distinguish these interglobular spaces from that of man by their morphology and it was also concluded that there was no difference in their manner of their appearance. 


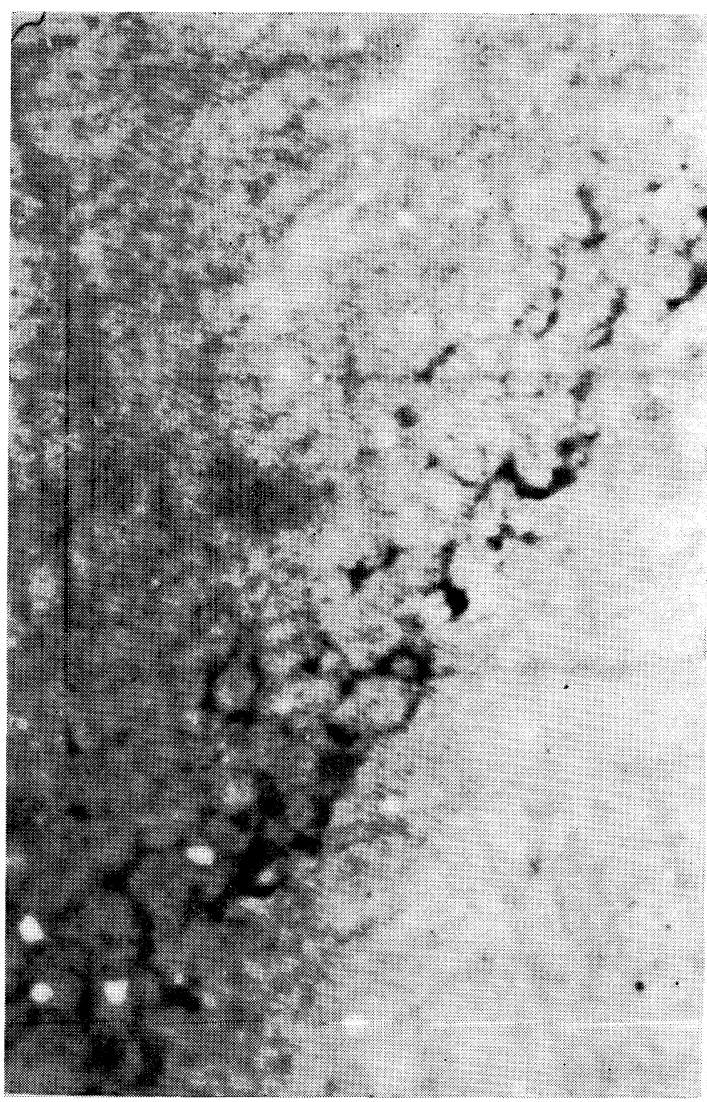

Fig. 1 A historadiograph of the interglobular spaces in the dog-tooth.

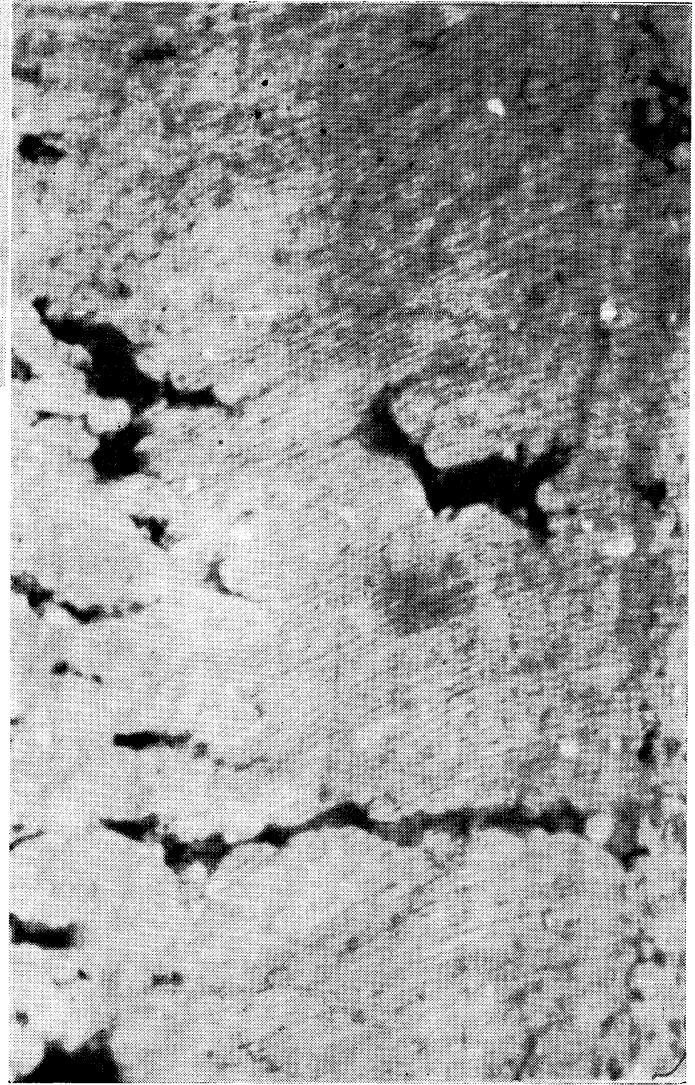

Fig. 2 A historadiograph of the interglobular spaces in the seal-tooth. 


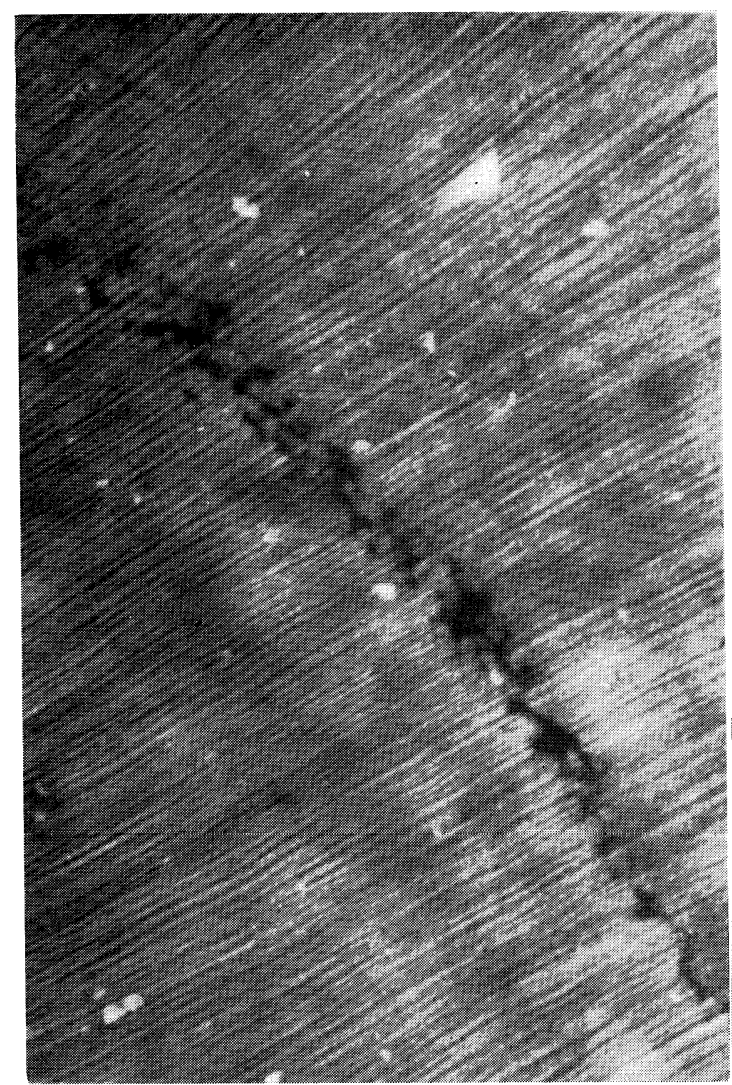

Fig. 3 A historadiograph of the interglobular spaces in the wild pig-tooth.

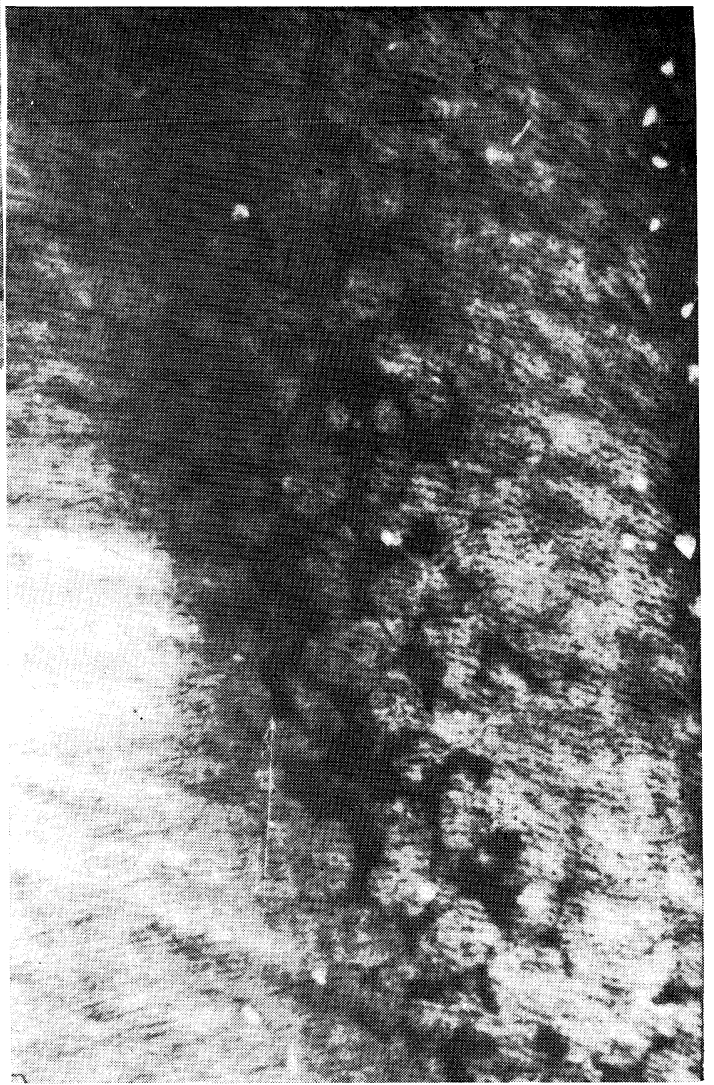

Fig. 4 A historadiograph of the interglobular spaces in the racoon dog-tooth. 


\section{Discussion}

Investigators including Katayama[7], Nishiyama[8], Evra[9], NaKajima[10] and IsoKAWA et al.[11] all confirmed the existence of interglobular space in human teeth with nearly $100 \%$ occurrence. With other mammalian teeth, however, the existence of this interglobular space has not been confirmed. Failure to do this is ascribed to the usual practice of obtaining 1 to 2 ground sections for observation.

Our study was made possible to obtain semi-serial ground sections through the use of thin sectioning machine by producing nearly ten or sometimes more sections from one tooth. These were further supplemented by the use of historadiographic technique. Conjoint use of thin sectioning and historadiographs aided us to determine the existence of interglobular space in all of 21 mammalin teeth studied.

\section{Conclusions}

1. From the fact that interglobular space was found in all of 21 mammalians, it was concluded that interglobular space existed as one of universal structures of these animals. Generally speaking, the existence of interglobular space in other mammalians than man was less easy to establish.

2. There was no difference in the appearance of the outline of interglobular space from mammalian species to species studied.

\section{References}

[1] Cohen, R. A.: The development of dental histology in Britain; Brit. dent. J., vol. 121, 59-71, (1966).

[2] Czermak, J.: Beitrage zur mikroskopischen Anatomie der menschlichen Zähne; Zeitschr. Zoolg., Bd. 2, 297-322, (1850).

[3] Kölliker, A.: Handbuch der Gewebelehre des Menschen; MöllendorfF, W.: Handbuch der mikroskopischen Anatomie des Menschen, Verdauungsapparat; Springer Verlag, Berlin, 449708, (1936).

[4] MacQuillen, J. H.: Microscopy of the dental tissue; Dent. Cosm., Vol. 7, 449-455, 505-509, (1866).

[5] KollmanN, J.: Die Interglobularräume in der Substantia ebrunea der Zähne; MöllendoRfF, W.: Handbuck der mikroskopischen Anatomie des Menschen. Verdauungsapparat; Springer Verlag, Berlin, 449-708, (1936).

[6] Isokawa, S., Satomura, I., Misu, T., Hasegawa, T. and Honda, H.: Some historadiographs of human dentin structures; J. Nihon Univ. Sch. Dent., vol. 8, 191-197, (1966).

[7] Katayama, T.: Contoribution to the knowledge of the histological investigation concerning the interglobular spaces of human teeth; Shikka Shimpo, vol. 21, 495-504, (1928), (Japanese).

[8] Nishiyama, Y.: On the exhibition of the interglobular spaces in the Korean teeth; MinamiManshu Shikka Igaku, vol. 3, 9-18, (1929), (Japanese).

[9] ERva, F.: Untersuchung über das sogennante Interglobulardentin und die TomEs sche Körnerschicht; Cited from 10).

[10] NaKajima, T.: Über die Verteilung und der Entwicklungsgrad der Interglobularbezirke in menschlichen Zähnen und ihre Beziehung zum Lebensalter; Kokubyo Gakkai, vol. 13, 1-9, (1939), (Japanese).

[11] Isokawa, S., Kosakai, T. and Kajiyama, S.: Interglobular dentin in the deciduous tooth; J. dent. Res., vol. 42, 831-834, (1963).

[12] FujitA, T.: Text-book of dental histology; Ishiyaku Shuppan, Tokyo, (1957), (Japanese).

[13] Breuer, R.: Demonstration mikroskopischer Bilder von Zahnschliffen des Höhlenbären; Zeitschr. Stomat., Bd. 24, 429-439, (1926). 
[14] Adloff, P.: Tomessche Körnerschicht, Interglobulardentin und Vasodentin in einigen Säuertierzähnen, zugleichen Beitrag zur Kenntnis des Gebißes von Orycheropus und Stammesgeschichte dieser Tierform; Vjschr. Zahnhk., Bd. 46, 207-258, (1930).

[15] Dieckmann, E.: Ein Beitrag zum Kenntnis von den sogenannten "Interglobularräume" in menschlichen und tierischen Zahn; Dtsch. Mschr. Zahnhk., Bd. 43, 653-672, (1925).

[16] Goldberg, F.: Die Bedeutung der Interglobularräume; Dtsch. Mschr. Zahnhk., Bd. 42, 461468, (1924).

[17] Mummery, J. H.: The microscopic and general anatomy of the teeth; 2nd edition, Oxford Univ. Press, London, p. 247, (1924). 